\title{
The opaque gendered lens - barriers to recruitment and career development
}

\author{
Christina Scholten and Hope Witmer \\ Department of Urban Studies, Malmö University, Malmö, Sweden
}

\begin{abstract}
Purpose - This paper aims to reveal gendered leadership constructs that hinder a competency-based view of leadership in Swedish-based global companies and the implications for leadership recruitment and development to top management positions.

Design/methodology/approach - The paper is based on qualitative semi-structured interviews, which have been analyzed using a gender analytic framework to identify how senior management, Human resource management and leadership trainees are discussing leadership and career development.

Findings - Three themes were identified as clouding the issue of gender-equal leadership practices thereby creating an opaque gendered lens of who is defined as eligible for leadership positions. The three themes were: symbols as gendered images, counting heads - preserving the existing system and illusive gender inclusion.

Research limitations/implications - Recruitment practices were identified as contributors to homosocial practices that perpetuate male-dominated leadership representation. However, specific recruitment practices were not fully explored.

Practical implications - The potential use of gender equality as a sustainable management practice for competitive organizations to recruit and develop talented people.

Social implications - To create resilient and gender-equal recruitment and leadership development practices.

Originality/value - This research offers an original perspective on gender representation at the senior management level in global companies by revealing gendered leadership constructs in the leadership recruitment and development process as antecedents to unequal gender representation in senior management positions.
\end{abstract}

Keywords Corporate culture, Leadership, Recruitment, Management development, Gender equality Paper type Research paper

\section{Introduction}

Despite decades of gender equality policies and affirmative action in Sweden and globally, women in top management positions are still under-represented in both the private and public sectors (Adler, 1993; Billing, 2011; Ely et al., 2011; Gallant, 2014; Muhonen et al., 2012;

(C) Christina Scholten and Hope Witmer. Published by Emerald Group Publishing Limited. This article is published under the Creative Commons Attribution (CC BY 3.0) licence. Anyone may reproduce, distribute, translate and create derivative works of this article (for both commercial and non-commercial purposes), subject to full attribution to the original publication and authors. The full terms of this licence may be seen at $\mathrm{http} / / /$ creativecommons.org/licences/by/3.0/legalcode

The authors would like to thank Prof. Lena Gonäs and the workshop no. 10 participants in the FALF conference in Gothenburg in June 2014, and Prof. Tuija Mohonen and colleagues at CTA for valuable comments on earlier drafts. The authors thank the Swedish Innovation Agency, Vinnova, which has funded the research projects from which data has been analyzed in this article.
The opaque gendered lens

Received 30 September 2015

Revised 1 March 2016

11 July 2016

30 September 2016

Accepted 26 October 2016 
GM

32,1

48

Oakley, 2000). There are still no signs of senior management teams in global organizations being gender equal or that women are equally accounted for in CEO positions (Kiaye and Singh, 2013; Kunze and Thorburn, 2014; Joshi et al., 2015). The search for global leadership talent and the need to develop internal processes to identify and develop employees to become tomorrow's leaders is a growing demand (Chambers et al., 1998; Mäkelä et al., 2010; Schuler et al., 2011; Dragoni et al., 2009; Tienari et al., 2013; Gladwell, 2002). With increased global competition and an expanding number of small- and medium-sized companies becoming global, the competition for young talent has increased (Scullion and Collings, 2011). At the same time, the gender gap between women and men in senior management positions continues. One prevailing theory is that women are not provided equal opportunities early in the leadership identification process. This lack of opportunity starts with leadership recruitment and continues throughout the talent management process (Ohlott et al., 1994; King et al., 2012; Hoobler et al., 2014; Ely et al., 2011). One explanation for why women are not identified or considered as potential candidates for executive positions is given by Tienari et al. (2013, p. 4) who point to the search for executive candidates as a closed process conducted by head hunters and the "new boys network". This type of recruitment is an example of homosocial practice that contributes to the gender construction of executive candidates as male and perpetuates the reproduction of male top management (Lipman-Blumen, 1976; Holgersson, 2013).

In Sweden, gender equality in work life has been on the political agenda since the 1970s when a delegation on women's work life conditions was initiated. Gender equality policies have continued to develop, and Sweden, together with the Nordic countries, has been acknowledged as forerunners in gender equality (Daly, 2005). Despite being successful at policy levels and introducing legislations and programs to reduce the inequality between men and women, women are still under-represented in senior management positions. According to Swedish National Statistics, only 5 per cent of the chairpersons and 6 per cent of the Managing Directors in private-sector-listed (stock exchange) companies are women (Tables I-III). In public sector companies, the number of

Table I.

Number and sex distribution in boards and management teams of listed companies in Sweden, 2013

\begin{tabular}{lrrrr}
\hline & \multicolumn{2}{c}{ Number } & \multicolumn{2}{c}{ Sex distribution \% } \\
Position & Women & Men & Women & Men \\
\hline Chairperson & 11 & 220 & 5 & 95 \\
Managing director & 14 & 217 & 6 & 94 \\
Board members & 359 & 1 & 157 & 24
\end{tabular}

Sources: Styrelser och revisorer i Sveriges Börsföretag 2012-2013, SIS Ägarservice AB Boards and Auditors in Sweden's listed companies (Statistics Sweden, Women and men in Sweden, 2012)

Table II. Sex distribution in boards and management teams of public service companies, 2002 and 2013

\begin{tabular}{lccccc}
\hline & & & & $2013 \%$ & \\
Position & Women & & Men & Women & Men \\
\hline Chairperson & 13 & 87 & 37 & 63 \\
Managing Director & 12 & 88 & 29 & 71 \\
Board member & 37 & 63 & 47 & 53
\end{tabular}

Source: Ministry of Finance, Annual report for government-owned enterprises (Statistics Sweden, Women and men in Sweden 2014) 
women in these positions has more than doubled (Tables I-III) demonstrating that there has been progress in the public sector but not in the private sector, which is the focus of this study.

In regard to the background presented above, we can see that women are progressively entering leadership positions in public service companies; however, they continue to lack representation in the private sector. In an environment where legislations on gender equality and the implementation of tools to promote gender-equal practices has continued to develop, our curiosity regarding this seeming contradiction led us to the question, why are women still under-represented in top management positions in private companies? Furthermore, many organizations promote corporate values and ambitions that present the image of a modern, attractive, gender-equal workplace while lacking equal representation at the senior management level. This led to our interest in learning more about this phenomenon from the perspective of recruitment of talented people. The aim of this paper is to identify if gendered leadership constructs exist that potentially distort a competency-based view of leadership in Swedish-based global companies and the implications for leadership recruitment and development to top management positions. This paper will also explore gender mainstreaming as a working model for gender-equal recruitment processes. The research questions were:

$R Q 1$. How are organizational constructions of leadership articulated according to gender?

RQ2. What impact do the constructions of the ideal leader have on recruitment and leadership development practices?

The article is based on two case studies, one from the retail industry and one from the food industry. Both cases are gender-coded female industries and global businesses (Jönsson et al., 2014). In this article, we have concentrated on findings from interviews conducted with human resource (HR) managers, senior managers and aspiring leaders in the food and retail industry. The article is structured as follows:

- first, we outline gender equality as a strategy for institutionalized change and specify our theoretical perspective;

- we then present the research design, methodology, empirical data and finding; and

- finally, we present our conclusions and make recommendations for further research on gendered organizations and gender-equal leadership recruitment and development.

\section{Gender mainstreaming - a model for gender-equal recruitment of managers?}

The Swedish government initiated a public investigation on societal power relations in the late 1980s (SOU, 1990, p. 44). An important theoretical contribution in the investigation was the gender system approach that includes the following propositions:

\begin{tabular}{lcccr}
\hline & & & \multicolumn{2}{c}{ Sex distribution \% } \\
Position & Women & Men & Women & Men \\
\hline Chairperson & - & 4 & - & 100 \\
Director General & 1 & 3 & 25 & 75 \\
Board member & 14 & 15 & 48 & 52
\end{tabular}

Source: Ministry of Enterprise, Energy and Communications (Statistics Sweden, Women and men in Sweden, teams of public service 2012) 
GM

32,1

- gender is socially constructed;

- what is historically, socially and culturally constructed as male is viewed as superior to what is constructed as female; and

- the gender system acknowledges power structures that subordinate what is considered feminine compared to masculine (SOU, 1990, p. 44; Hirdman, 2003; Connell, 2002).

In 1991, the Swedish Gender Equality Act (2 SFS, 1991, p. 433) further addressed power structures and was based on both gender system theory and feminist theory. At this same time, Yvonne Hirdman introduced the concept "gender contract model" which identified that men and women together keep intact the gender power inequity of subordinating women to men.

The gender system theory was influential in the development of Swedish gender policy. Therefore, when gender mainstreaming was introduced in the mid 1990s, Sweden was well prepared to integrate it as a method for working with gender equality. Gender mainstreaming is a process of integrating gender equality in all work groups and organizational processes versus treating it as a separate set of processes. It was introduced as a way of moving gender equality into core organizational activities and away from organizing gender equality measures as side projects secondary to the core business. Introducing gender mainstreaming as a strategy for improving gender equality made previous methods for taking women's status into consideration obsolete (Squires, 2007; Rönnblom, 2011). As Squires and others (Lombardo et al., 2009) have identified, introducing gender mainstreaming as the method for gender equality professionalized the question of women's rights. One outcome of choosing gender mainstreaming as the only method was a vast amount of literature on how to make it work in practice. The literature highlights three aspects of working with gender mainstreaming:

- mapping the representation of men and women in the organization;

- mapping the distribution of resources according to women and men; and

- finally, analyzing the distribution of gender and resources (Svenska Kommunförbundet, 2002).

The feminist model, which the Swedish gender equality policy is based on, has been criticized for not acknowledging power dimensions within the two sex categories and for not taking race into consideration. Gender mainstreaming has also been criticized for being inconsistent (Verloo, 2007; Walby, 2005) and for its different, and sometimes opposing, theoretical formulations for handling the sameness/difference distinction (Walby, 2005.) Whether it should be viewed as theory or method is another contentious issue (Walby, 2005). Gender mainstreaming is what Mark (2007) defines as "system preserving” gender equality. According to Mark (2007), the analysis needs to start by questioning the ideals of the organization or business and revealing gendered embedded norms (Verloo, 2001; Walby 2005). If used in accordance with feminist theory gender mainstreaming can be used as an innovative process for developing organizations and businesses so they move toward systemic, sustainable change rather than cosmetic, surface changes. We consider gender mainstreaming as a model to enhance a more gender equal recruitment process, focusing on the structural dimensions of gender in society. Being aware of the theoretical objections, in this article we will use it as a tool to understand how competence and recruitment is narrated by managers, HR experts and management aspirants. 


\section{Setting the scene - retail business and food industry}

The retail business and food industry are highly diverse sectors in the Swedish labor market but are referred to as women dominated labor markets. The food industry is the fourth largest manufacturing industry in Sweden. In 2012, 53,000 people were employed by the industry and it contributed to 2 per cent of the GDP. In 2010, the total revenue was 165 bn Swedish kronor. According to National statistics, the gender quota in the food business is about equal; however, the internal labor market is gender segregated according to both hierarchy and work tasks. The jobs occupied by women require fewer qualifications and only 20 per cent of the managers are women (Ledarna, 2014).

In the Swedish context, the retail and food industry are described as places where primarily women work. In retail, there are more women than men and they also out-number men in first line management positions. In regard to the more senior management positions, only 30 per cent of these positions are filled by women (Ledarna, 2014).

The strategies used to address recruitment and leadership development is rooted in the type of talent required in the particular industry. The company's philosophy of the type of talent needed to strategically position their organization as relevant and competitive is also considered as a part of their recruitment and development strategy. Historically, the food industry has based their recruitment of managers on individual experience within the company thereby limiting the pool of potential leaders. However, because the food industry has developed and is competing in the global market, they have professionalized management positions and broadened the scope of their recruitment. In the retail business, practical, hands-on experience is described as the path to leadership and is the primary focus of recruitment and leadership development. Managers are viewed as effective based on how they daily contribute to leading and developing their team.

\section{Research design and methods}

This article is based on data from two case studies of industries that operate in the global market: food and retailing. The food industry project focused on how an innovation hub could use gender equality in food businesses to develop and enhance innovation processes (Scholten, 2012). The food industry data was gathered from: semi-structured interviews with board members, stakeholders, trainees, students, researchers and industry representatives and statistical reports on gender quotas (Scholten, 2012).

The retail industry project focused on gender equal practices within "Swedish" leadership in a global company (Jönsson et al., 2014). A single global firm was used as the case and one of the authors followed a 20 -week trainee program with 20 participating trainees. The author took part in retreats, workshops, participant observations and interviews with the mentors and trainees. Qualitative data were gathered from observations, semi-structured interviews and field notes. The interviews were transcribed verbatim. The two research projects can be described as having a multiple case-study research design (Yin, 1994) which gives the opportunity for a nonlinear research process (Callerstig, 2014). This method helps to develop the research project in line with both a conceptual theoretical framework (feminist theory) and inductive, qualitative empirical generated data. Gender, gender equality and organization were common features of both projects. It is important to note that the data from the food industry were collected from multiple organizations, whereas the data retrieved from the retailing project were gathered exclusively from one organization. The reason for this difference is that the food industry project provided access to an innovation hub including several companies, whereas the retail research project provided access to only one company. Combining the data from these industries is of value because both cases are 
GM

32,1

52

gender-coded female industries and global businesses; thus, the argument put forth in this paper is strengthened.

The sampling procedure occurred as follows. In the food industry project, the first interviews were conducted with the board members of the innovation hub. As a result of these contacts, access was provided to CEOs and senior managers of the leading food companies in Sweden. In addition, the food industry board recommended exploring informal networks by interviewing HR managers. Using the snow ball sampling method (Babbie, 2001), the first interviewee recommended the next person to be interviewed.

In the second project, there was direct access to the Swedish CEO for the global retail company. He gave access to the organization where the researchers individually identified key informants. The key informants comprised HR managers and project managers. In addition, the National Human Resource manager was also interviewed. This individual provided access to the aspirant training program (training for young aspiring leaders). All participating managers of the training program, and all trainees in the program were interviewed.

In total 50 people, 29 women and 21 men were interviewed. Senior management included CEOs and board members, 7 women and 10 men. The first line managers included HR managers and project managers, six women and two men. The management trainees comprised 16 women and 9 men (Table IV).

The interviews lasted between 35 and 90 min and were conducted at each interviewee's workplace. The interviews focused on different aspects of gender equality, organizational development and career development. The board and senior managers as well as the HR managers were asked about their individual experiences of career development and gendered power structures at the workplace. The interviewees reflected upon different situations they had experienced. They explained how previous life situations had provided or restricted opportunities and leadership possibilities and how this impacted their experience or motivation to become managers.

Qualitative research design generates large amounts of data, which need to be sorted and condensed in a structured manner (Kvale, 2007). The data analysis was organized using a grounded theory approach influenced by Strauss and Corbin (1998). The empirical findings were analyzed using theories from feminist research on gender, organization and gender equality. This process of alternating between review of the findings and theory was a significant part of an abductive analysis process (Callerstig, 2014; Dubois and Gadde, 2002; Cowley and Heath, 2004). The feminist theories used in analyzing the empirical data were based on Acker's (1990) model of gendered organizations as well as more recent feminist research on gendered organizations and gendered leadership (Billing 2011; Gallant 2014; Holgersson, 2013; Liu et al., 2015; Rees and Garnsey, 2003). The theoretical framework helped identify the gendered structures embedded in the organizations' cultural norms and to understand if, and how, corporate culture works for or against gender inequalities in the areas of leadership development and selection.

The analysis began by reading transcripts of the interviews informed by the theoretical perspective of gendered organizations (Acker, 1990) and the desired management qualifications as defined by the industry and companies in this study. While analyzing the

Table IV. Interviews conducted: industry and gender distribution

\begin{tabular}{|c|c|c|c|c|c|}
\hline Gender & $\begin{array}{l}\text { Food industry CEO, } \\
\text { senior manager, } \\
\text { board member }\end{array}$ & $\begin{array}{l}\text { Food industry } \\
\text { HR manager }\end{array}$ & $\begin{array}{l}\text { Food industry, } \\
\text { trainee }\end{array}$ & $\begin{array}{l}\text { Retail business, HR } \\
\text { manager and } \\
\text { project manager }\end{array}$ & $\begin{array}{c}\text { Retail business, } \\
\text { trainee }\end{array}$ \\
\hline Men & 10 & - & 2 & 2 & 7 \\
\hline Women & 7 & 2 & 4 & 4 & 12 \\
\hline
\end{tabular}


data, there was a specific focus on the contradictions between policy and praxis within the areas of leadership recruitment and development. Using this method, passages were identified in the interview transcripts that referenced these aspects of gendered management. The relevant passages in the interview content were coded in line with grounded theory principles (Cowley and Heath, 2004).

\section{Findings}

The aim of this study was to identify if gendered leadership constructs exist that distort a competency-based view of leadership in Swedish-based global companies and to explore the implications for leadership recruitment and development to top management positions. To obtain a multilevel organizational perspective, the interviews were conducted with senior managers, first-line managers and management trainees.

In the following section, we discuss our findings thematically under the following headings: symbols as gendered images, counting heads - preserving the existing system and illusive gender inclusion.

\section{Symbols as gendered images}

Leadership is a position imbued with various symbols, often referring to power, control, independence and prestige (Acker, 1990). When symbols are attached to gender and the imbued power, control, independence and prestige associated with these symbols, it perpetuates a gendered construct of leadership. These gendered constructs often reinforce the spatial and organizational division between women and men (Acker, 1990). In the interviews, both women and men gave examples of leadership constructions as gendered practice accompanied by specific artifacts and behaviors.

A former (woman) CEO recalled when she accepted the position as a senior manager, her fellow male colleagues tested her in a competitive manner. Her strategy in response to this was to be one of the boys, and not just any of the boys but the lead character. Being competitive was her strategy for establishing her authority in what she described as a tough and masculine setting. She also decided to compete on their terms by systematically making sure that she had all the symbols of a successful industry leader. This form of establishing her authority included the most expensive and exclusive company car; the most high-tech cell-phone and displaying the highest scientific-industry-ranked journals as her reading material of choice. She explained that she did all this just to demonstrate that she was "playing with the boys on their own turf". She further explained that when a woman reaches a top-position like she has as CEO, they continue to be questioned by male subordinates and have to use symbols of power and prestige to "stay in the game".

One woman interviewee gave a detailed description of how she felt when selected for a "traditionally" male senior manager position and subsequently encountered envious male colleagues. Her selection was based on both her competencies and experience in the core business as a production manager. The production manager position is a technical job viewed as both a symbol of masculinity and an unstated prerequisite for management. Her statement is given as follows:

$[\ldots]$ There are too few women working directly in the field - on the production line where they can directly experience results based on their own effort. I believe this pattern must be broken and women must have the opportunity to work on the production line or they will never get ahead (woman corporate leader, food industry B).

In addition to this experience, she also had the required skills to work in an international work environment. Although her skills and experience exceeded her male predecessor, he was retained by the company as her mentor. She was convinced that he was retained in the capacity as mentor 
to add "male" credibility to her position, a position "understood" to be only for men. This perception of competency hinders women without management experience on the industry floor from reaching senior management level positions. This is an example of the gendered contract that, Hirdman (2003) argues, maintains the (un)even gender balance.

To further strengthen her points, this corporate leader gave examples of being influenced by male mentors throughout her childhood while concurrently retaining her female identity. She described being supervised by her uncle and inspired by male professionals that were a part of her family during her childhood. She explained sharing a strong identification with men - her father and his colleagues - but felt that she had retained her female identity and had not taken on the image of tomboy. Others interviewed described themselves as tomboys who have always found it natural to socialize and identify with men and their interests:

[...] When I was growing up, I had primarily male friends. I had trouble understanding myself, for example, why I found it fun to shoot a slingshot and why it wasn't fun for me to play with dolls (woman manager in the food industry).

A younger aspiring leader in the retail business described herself as a tomboy on the path to leadership. She explained her adopted strategy of showing off for the male colleagues as a way to be noticed and position herself for consideration of leadership positions. She explained that if she can be viewed as masculine, then she has a better chance of being considered for leadership.

In accordance with the sociocultural construction of femininity, there were examples in the organizations studied of women reduced to qualities associated with their sex and described as docile, caring and compliant (Leidner, 1991). In the food industry, women trainees were referred to as a nice complement to the work environment. This assessment was based on qualities of caring and kindness rather than on knowledge and skills. Their university degrees had become tokens of a more professional environment, rather than being an indicator of an acquired skill level. They worked in a predominately male department where few had or valued university diplomas. A similar situation was also found in the retail industry as illustrated in the following quote:

[...] Getting more girls I think is good, it lightens the mood, you get more points of view more backgrounds perhaps, many guys have pretty similar backgrounds [...] while the girls might have worked in completely different professions so it is [...] Yes, it is a positive factor that we have received more girls, definitely (man manager, retail industry).

The accepted societal gender contracts have impacts on how qualifications and gender are connected in society and is mirrored by these organizations. Even if the food and retail businesses are women-dominated sectors, the management teams are often male dominated, resulting in women managers being treated as secretaries or totally ignored at meetings:

[Reflecting on her experience in the boardroom and on project teams] [...]just like all the women who step into the boardroom or projects. You can sit and express as many ideas as you like and nobody listens, but then a man says the same thing a few minutes later, and all the sudden [...] wow, what a great idea (former woman manager in the food industry).

Furthermore, the retail organization and the food business, although claiming to be modern inclusive organizations, continued to display visual representations - pictures on the walls and in its literature - of older, white, men as leaders in the organization. The images portrayed a construct of leadership as a heterosexual, white male. Upon reflection, one of the HR managers made the statement that this may be why young people often have an "old-fashioned idea of leadership". 
In order for gender mainstreaming to be implemented as a working model for gender-equal recruitment, the processes need to be translated into every day organizational practices. As mentioned in the introduction, gender mainstreaming aims at fundamentally reorganizing institutions at a system level (Mark, 2007; Verloo, 2001, p. 3; Walby, 2005). This reorganization implies both quantitative and qualitative aspects of the organization, which sometimes makes gender mainstreaming a challenge to deal with theoretically. The quantitative dimension focuses on gender quotas in relation to representation in different settings such as board member representation and access to resources. The qualitative dimension has an imbued aspect of power in relation to gender and at the same time is linked to gender identity and social constructivist perspectives on identity. The qualitative perspective sometimes works in opposition to the quantitative understanding of gender equality (Powell et al., 2009). Just focusing on the singular quantitative aspects can become an exercise in counting heads that preserves gender numbers without making integrated systemic change that alters structures or processes. In this section, we are focusing on the quantitative aspect of the gender mainstreaming process.

The question of numbers and gender quota is relevant in the organizations studied as illustrated in the following examples. A young female student who is engaged in recruiting activities for the food business industry reflected upon a board meeting. In this meeting, she and her female colleagues were greeted by the male senior managers with the following comment "where are the boys hiding?" She retorted with "where is the board hiding the women?" The male board members had expected more male students aspiring to leadership positions in the food industry and the female students had expected a more gender-equal representation on the board. A representative of the organizing committee for the event explained that the gender balance in the student group is representative of the number of women compared to men who are attending university and specializing in food technology.

In the retail business, counting and numbers was an argument for not having to consider the question of gender equality. HR managers explained that there was no gender equality problem because the company attracts many young, well-educated women who are interested in working at the company. To support the argument, the HR manager presented a document that numerically showed a 50-50 gender split of warehouse managers. This was used as a justification that they had reached the gender equality goal. Furthermore, gender was about even in the management trainee program. In rebuttal to this argument, several of the HR managers stated that the gender quota scale had started to tip in the other direction. Their view was that if there were gender-equality issues to address, it was about recruiting men as there were more women than men working in the warehouses. From this perspective, the men were gaining affirmative action without anyone acknowledging it was occurring. In these discussions, the HR managers discussed gender equality from a numeric standpoint, referring to gender equality as the number of men and women; however, they had difficulty making this distinction when referencing men and women being given the same leadership opportunities. Gender equality was viewed as a strategy of equal numbers and managing salaries, not as a recruitment strategy connected to leadership.

When the HR manager was asked about gender equality from an organizational perspective, she emphatically stated that gender equality is an individual issue, "it is every one's responsibility to develop him or herself for a more senior position". Furthermore, she drew a distinction between gender numbers and recruitment processes reflecting an ambivalent attitude toward this issue: 
GM

32,1

I don't use the gender equality plan as a tool. We use the plan in order to have control and make sure there are no skewed salaries according to gender, but not in recruiting processes, because we need to have good candidates (female, HR-manager, RB).

This statement illustrates that the HR manager in the retail business was unaware of the difference between gender equity and gender equality. Gender equality entails working with structural factors related to distinctions based on gender.

In contrast to the previous HR manager's response, a former CEO from the food industry framed her concern about the slow pace of recruiting talented women to senior positions from a broader contextual perspective. She expressed her belief that the onus of the responsibility for gender-equal leadership is not an individual responsibility but should be viewed from an organizational and societal perspective.

She further described how she was often asked to make statements regarding organizational implementation of gender equality policies. Despite her strong belief that more women should occupy top leadership positions, she felt somewhat offended when questioned about this topic. When this occurred, she felt she was not valued as an individual but treated as a female in a symbolic position. Her additional concern was that the government was selecting the easy way of addressing the issue by threatening boards of private companies to reach certain quotas instead of dealing with the necessary structural changes in organizations and society:

[...] but my point is that it's a social issue, how men and women are portrayed in advertising all reinforce this issue. As I see it I think it has consequences for people's career choices because of what they've seen around them. For example, how is what women do portrayed? [...], what do men do? These images, sit deep, deep, deep, deep in self-image and identity, and includes [who we view as] role models, this is a big deal (woman CEO, in the food industry).

While the CEO was addressing the structural dimension of unequal terms for women and men, the trainees and managers referenced an individualized viewpoint that focused on getting the most qualified person in the position regardless of gender. When asked about gender quotas, the leadership trainees in the retail company stated "[...] we are not feminists or supporters of affirmative actions". They put forth the argument that what is most important is getting the right person, based on qualifications into a vacant position regardless of gender, disability or ethnicity. The HR managers also referred to characteristics of qualified individuals and the importance of selecting the right person. The retail business used the concept "the many people" as a statement of inclusion for any under-represented group. In the interviews, when HR managers were asked about gender equality policies they reflexively shifted the discussion to the problem of attracting people with ethnicities other than Swedish to management position. They retorted with statements like: "They don't apply for the positions" (senior male HR-manager, RB). This argument positions the individual worker as the problem rather than the organization's response to policy formation and organizational structural conditions as the problem.

The intention to count heads and distribute resources evenly does not shed light on how recruitment processes are developed or how competencies are constructed and valued. Feminist analysis of unequal organizational conditions is often reduced to technocratic measures of numbers and figures (Wittbom, 2009), which have symbolic values but does little for gender equality. It becomes what Mark (2007) describes as a system preserving the gender mainstreaming approach. Verloo (2001, p. 9) explained the problem in the following way:

$[\ldots]$ because the regular actors have to implement the strategy, it is unavoidable to frame the strategy and all its elements in terms that are meaningful and positive to them. Newly proffered frames (such as gender mainstreaming in this case) must "resonate" or "fit" with the existing frames within which the regular actors, or the dominant elite among those actors operate. 
In Sweden, gender equality policies have been on the political agenda for a long time. The government has supported gender equality policies in public organizations and stimulated private organization initiatives. However, to move from policy into practice is difficult, and despite the historical political movement for gender equality, there are still unequal structures being reproduced in Swedish organizations. There are examples where gender mainstreaming has been successfully implemented in private companies, while also examples of organizations simply fulfilling the basic legislative requirements. The lack of powerful instruments for enforcing organizations to fulfill the mandates of gender equality legislation can undermine the original intentions of the legislations. Instead, the result can be the illusion of addressing gender while the basic structures and processes that perpetuate these inequalities remain unaffected.

The government's aim to ease the implementation process of gender mainstreaming by supporting the work and funding of organizations that comply with the quantitative part of the process can result in weak processes that do not initiate change. An example of this was bluntly explained by one interviewee in the following comment: "you tick the box for gender equality in the application sheet, and we get the money" (board member, FB). The primary focus was to get the money by meeting the quota, not necessarily to implement gender equality. A rebuttal to this was that handing in contracts and documents demonstrating women are equally participating in the activities identified by the funding requirements can be an acceptable and easy strategy for working with the complex and difficult issue of gender equality.

Projects implementing gender equality strategies (mainly through gender mainstreaming) play an important part in developing their company's image of being modern and relevant. Furthermore, HR managers in the food industry explained that it is sometimes difficult to work with these issues because the companies are part of a large international consortium. Challenges arise when a new country manager or European area manager is recruited, often from abroad, and lacks understanding of Swedish legislations and ideas about gender equality.

In the retail business, a senior HR manager was concerned about the image of gender inclusiveness in relation to leadership development in young, talented co-workers. He believed his younger colleagues had leadership ideals based on old models of hierarchical leadership, "someone sitting on the top floor making decisions for other people". However, his experience did not correspond with the ideas of the young people taking part in the leadership-training program. These trainees discussed leadership and business development in the context of strong teams which is more indicative of shared inclusive leadership. In the food industry, the trainees expressed concern about what they experienced as traditional values embodied in masculine images of leadership that were promoted as aspirational ideals within the organization. This impression was confirmed in the interviews with women leaders in both the retail business and the food industry

It is important to note the idea of management development and professionalization differed between the retail company and the food industry. The food industry was moving toward becoming more professional and focused on attracting people with university diplomas in business administration and accounting. To broaden their leadership recruitment, training and to present a more professional image, they used an external agency to manage this process. The retail company perceived those in the well-educated category as problematic and made an intentional decision in their recruitment and promotion processes to prioritize those with experience in the retail 
GM

32,1

industry. Their recruitment and leadership development processes were done internally with an emphasis on company culture and values.

In the retail industry as well as in the food industry, HR management gave examples of gender equality as part of an external inclusive image the organization used as a strategy for recruitment and marketing. In the food industry, HR managers expressed awareness of the importance of portraying an image of inclusion so the business appears as a relevant and attractive place to work for young, well-educated potential leaders. According to the food industry HR managers, one of their challenges is working against an old-fashioned, dull image of the food industry based on farming and agriculture and making the business more interesting to young, well-educated people. When referencing the external image projected in the retail business and food industry, senior-level managers shared success stories about how the organization has developed a more modern image. The examples they used were about combining family and work responsibilities as defining characteristics of a modern organization. In modern organizations, they explained, both men and women have family responsibilities. Family leave policies were used as one example of gender equality within their organization. In this way, policies were used to create the image of gender equality without referencing embedded cultural norms and values within the organization.

In regard to the statements made by HR managers and trainees, it is important to be aware of what is needed to attract and recruit talented young people and to systematically work to project an image of a modern, gender equal organization. Along with projecting this image, it is important that the supporting values be implemented and observed in every day practice.

An example of the inconsistency in everyday practice is illustrated in the following interview with the HR manager responsible for the retail industry leadership trainee program. The discussion was about the last session of the program when the aspiring leaders are presented to the global management team. The discussion started with the topic of gender quotas and equal leadership opportunities and ended by discussing women and men as biological individuals. When the aspiring leaders met the global management team - one of eight was a woman and she was responsible for human resources, not a core business unit - they challenged the unequal gender representation as inconsistent with company policies. When the HR manager was asked by the trainees about the progress of men and women in the area of career development, the reasoning supporting her response was based on women and biology. The HR manager acknowledged that it might take longer for women to pursue their careers. She explained:

It's us who carry the children, nothing we can do about it, is there? This situation contributes to the gender divided labour market in general and to the in-house gender structure specifically [...] perhaps it takes a little longer for women, if you have children in the middle of your career, even if the fathers takes more and more parental leave, there is still a huge difference [between women and men taking parental leave], of course that can be a setback for women (woman HR manager, retail business).

In the food industry, the analysis of why women tend to lag behind in their leadership development is also based on women as child bearers:

I would like to say, that it is harder for a woman to pursue a career than for a man [...] regardless of the sharing of paternity and maternity leave, it is actually the woman who gives birth to the child and usually takes a larger part of the time, that makes you lose momentum and opportunity (woman HR manager, retail business). 
The illusiveness of an inclusive organization has its roots in normalized routines of the business and its corporate culture and values. This section shows that even if there is an awareness of gender equality and its importance to attracting talented people and the implementation of gender equality activities (gender mainstreaming), the traditional values of gendered responsibilities in work-life and family-life seems to automatically identify women as biological individuals with responsibilities and preferences different from men. Biological sex becomes a screen between the idea of the gender-equal organization and its practice. This screen also inhibits recognition of the difficulties men have organizing career and family-life. Instead of investigating the relationship between the work conditions for women and men, gender equality becomes something only important for women (Verloo, 2007). As a result of this screen, asking questions about gender stereotypes, the impact these stereotypes have on what is considered as "right qualifications" and how these qualifications are identified and acknowledged becomes "business as usual" which impacts who is considered as a suitable candidate for a management position. If organizations are to become gender equal and if gender mainstreaming is going to be as operational as suggested by these organizations, the everyday praxis of the business needs to be reconstituted by using gender analysis to create what Mark (2007) describes as "system changing gender mainstreaming processes". Framing the discussion from this perspective and implementing such a strategy is difficult to implement because it puts emphasis on taken-for-granted, everyday practices and questions the very foundation of the organization's values (Verloo, 2007).

\section{Discussion}

The intent of this research was to explore how culturally manifested norms of the ideal leader impact ideas of who is defined as talented and viewed as a potential leader. The interviews identified multiple examples where constructions of the "leader" are deeply interwoven within corporate culture and thereby host gendered assumptions based on the dialectics of biology (Harding, 1986). For example, women had to be tomboys, competitive or take on male symbols of power to be considered for management positions. These expectations of eligible and acceptable criteria also sustain homosocial recruitment to top management positions (Holgersson, 2013, Lipman-Blumen, 1976) and determine the practices that junior managers adopt to be potential candidates for more senior assignments (Linghag, 2009). In accordance with the literature, top management is gender coded (Connell, 2002) as a specific masculine position where homosocial praxis has resulted in situations where a specific group of men are chosen and defined as potential senior leaders in favor of women and other men (Holgersson et al., 2014, p. 183). In the Swedish context, there is substantial evidence that the idealized senior manager is still founded upon criteria formed by the elite (white male businessmen) in Swedish society (Holgersson et al., 2014, p. 183). Specifically, these qualifications are an aggressive and competitive personality, (Holgersson, 2013, p. 460) more often related to a masculine gendered construction than a feminine gendered construction. Homosocial recruitment (Holgersson, 2013) seems to be the strategy for leadership identification and a sex-based confirmation precluding the possibility of recruiting talented people with different profiles. Because of these embedded practices, companies tend to miss opportunities to foster a professional attitude toward recruitment and judgment about competence, framing it as an individual issue rather than addressing it as an organizational issue (Holgersson et al., 2014). 
GM

32,1

60

Gender equality can be divided into two categories, a "system preserving" gender equality and "system changing" gender equality (Mark, 2007). System preserving is understood as a measure taken to balance unbalanced working groups by adding the under-represented gender. System changing measures emphasize ideas, norms and values related to the foundation of the organization's core activities. In this study, we are suggesting that the system preserving gender equality and the system changing gender equality needs to work together for significant change to be effected. Organizations have to work with balancing gender representation to make important visual statements of who is included. At the same time, organizations need to work with qualitative aspects by raising questions challenging what is considered as talent or which gender category is considered as trustworthy. Without addressing both aspects, there may be women waiting in the pipeline, yet the amount of power or influence these women have in the organization will remain unchanged (Broadbridge and Fielden, 2015, p. 1) As a result, gender equality turns into counting heads without strategic relevance, and the philosophy of inclusion and equity gets clouded over by traditions and norms that circumvent addressing the issues hindering organizational change and adaptation in these areas.

This research draws attention to two dimensions of gender equality policies that can make it difficult to conceptualize theoretically and practically. The quantitative dimension pays attention to gender quotas and representation in various settings, such as board representation and distribution of resources, that is who has access to specific resources. The second dimension is qualitative and has an imbued dimension of power between the gender categories. This qualitative perspective is concurrently linked to gender identity and social constructivist perspectives on identity, which at times works in opposition to the quantitative understanding of gender equality (Powell et al., 2009). We are not suggesting that organizational practices are consciously discriminating toward women, even if there are cases when companies have been accused of this practice. We are proposing that men being positioned as qualified persons based on sex and not skill-set is an unreflective and reflexive process leading to the preference for certain men to the exclusion of women (Holgersson, 2013, p. 454).

From this study, one can conclude that the management ideals in these two cases are based on masculine ideals. There are indices in the empirical findings that leads toward the analysis of competitive masculinity as a qualifying characteristic of the preferred manager (Connell, 2002; Pini, 2005). The focus has not been on the construction of what kind of masculinity the leadership ideal is built upon; the focus has rather been on the unarticulated gendered norms that become (unintended) barriers for women and those men who do not fit into the corporate masculine norms of talent. It appears inconsequential to have policy manuals for the creation of inclusive processes and strategies for the career development of women and men if the organization does not analyze its embedded norms of the ideal leader. Gender equality becomes a lip service, sometimes useful to the organization but mainly causing tensions in management structures and uneasiness among women and men. These individuals work in their organizations, thinking they share the same opportunities to develop as managers based on performance that is in line with the goals and objectives of the organization; however, what they experience in reality is vastly different.

If the organization does not acknowledge how gender inequality is generated and sustained in recruitment and development of potential leaders, the generated norms and values within the organizations will continue to blur the reality and restrict the pool for future leaders. The integration of gender equality can therefore be considered a method to develop the organization toward more inclusive recruitment, thereby broadening the pool of 
talent for potential senior managers. This will become increasingly necessary as international pressure increases the need to expand and grow young talent.

\section{Implications for research and practice}

Organizations are complex systems as are the embedded norms that influence organizational processes. Therefore, it is difficult to generalize the results of this study without further research to substantiate the claims. Recommendations for research include expanding the existing study to include an analysis of documents related to leadership recruitment and development as well as duplicating this study in other Swedish-based global companies. Recommendations for practice include:

- the inclusion of gender theory as a part of staff training for the purpose of equipping employees to recognize gendered structures from a critical perspective;

- train managers with skills to identify and address gender norms embedded in the system and which hinder the recruitment and training of competent leaders regardless of gender; and

- train senior managers to look outside their existing networks and bring together young aspirants, mixed gender and ethnicities for the purpose of discussing leadership competency, leadership development and good working environments.

These types of activities could be further monitored to identify their effectiveness in shifting the discussion from gender to qualifications and competencies that improve organizations' competitive positioning and sustainable business practices.

\section{Conclusion}

The purpose of this study was to identify if gendered leadership constructs exist that distort a competency-based view of leadership in Swedish-based global companies and the implications for leadership recruitment and development to top management positions. This study also explored gender mainstreaming as a working model for gender-equal recruitment processes. A gender analytical framework was used to identify underlying norms and practices embedded in the organizations that contribute to a gendered construction of leadership based on biological dialectics rather than skills and competencies. In the two case studies representing two global industries, the following three themes were identified as clouding the issue of gender-equal recruitment and leadership practices: symbols as gendered images, counting heads - preserving the existing system and illusive gender inclusion. Based on the interviews, we have reached the conclusion that leadership recruitment and development is negatively impacted by not reflecting upon the implications of embedded gender equality practices and their contribution to the development of the organization. These embedded practices are rooted in organizational norms and assumptions supporting divisions based on gender, affecting how leadership is defined and the desired qualities for recruitment. The consequence of treating gender as an issue of numbers without considering the ontological implications shifts the discussion from skills and knowledge to issues of male and female when identifying qualifications. These factors cloud the issue creating an opaque lens so that organizations do not reflect on who is carrying these qualifications. As a result, women are viewed as numbers to fill a quota based on sex rather than considered as knowledgeable and skilled contributors to the organization.

It is only by uncovering the more covert issues of stereotyping, tokenism, power, preferred leadership styles and the psychodynamics of male and female relations embedded in the organizational culture (Oakley, 2000) that one can begin to understand what hinders the leadership development process. The two cases presented in this article are far from the 
GM

32,1

62

only organizations trying to attract and manage a young, competent and skilled workforce. With more globally integrated businesses, the need for competent leaders has become a scarce resource. It is urgency that becomes the impetus for change, but change needs to be done with knowledge. In this article, arguments are brought together on how gender is constructed and put in action in organizations' everyday work. The researchers highlight how the present practices of counting numbers to fill policy requirements are creating an illusion of inclusion and as a result are not addressing embedded organizational structures and mind-sets. These mind-sets continue to enforce masculine constructions of leadership that circumvent women from leadership development and being viewed as potential knowledge bearers in the recruitment process. This perspective needs to be developed to further deconstruct these distortions, to better understand their impact on organizational performance and management development. As a result, strategies can be developed to provide gender-equal access to leadership development and contribute to creating modern and attractive organizations.

\section{References}

Acker, J. (1990), "Hierarchies, jobs, bodies: a theory of gendered organizations", Gender \& Society, Vol. 4 No. 2, pp. 139-158.

Adler, N. (1993), “Competitive frontiers: women managers in the triad", International Studies of Management \& Organization, Vol. 23 No. 2, pp. 3-23.

Babbie, E. (2001), "The Practice of Social Research, 9th ed., Wadsworth Publishing, Belmont, CA.

Billing, Y. (2011), "Are women in management victims of the phantom of the male norm?", Gender, Work \& Organization, Vol. 18 No. 3, pp. 298-317.

Broadbridge, A. and Fielden, S. (2015), "Introduction", in Broadbridge, A.M. and Fielden, S.L. (Eds), Handbook of Gendered Careers in Management, Getting in, Getting On, Getting Out, Edward Elgar Publishing, Cheltenham.

Callerstig, A. (2014), Making Equality Work: Ambiguities, Conflicts and Change Agents in the Implementation of Equality Policies in Public Sector Organisations, Linköping University, Linköping.

Chambers, E., Foulon, M., Handifield-Jones, H., Hankin, S.M. and Michaels, E.G. (1998), “The war for talent”, available at: www.mckinseyquarterly.com/article_print.aspx?L2 $=18 \& \mathrm{~L} 3=31 \& a r=305$, (accessed 10 October 2014).

Connell, R.W. (2002), Gender, Polity Press, Cambridge.

Cowley, S. and Heath, H. (2004), "Developing a grounded theory approach: a comparison of glaser and strauss", International Journal of Nursing Studies, Vol. 41 No. 2, pp. 141-150.

Daly, M. (2005), "Gender mainstreaming in theory and practice”, Social Politics: International Studies in Gender, State and Society, Vol. 12 No. 3, pp. 433-450.

Dragoni, L., Tesluk, P., Russell, J. and Oh, I. (2009), "Understanding managerial development: integrating developmental assignments, learning orientation, and access to developmental opportunities in predicting managerial competencies", Academy of Management Journal, Vol. 52 No. 4, pp. 731-743.

Dubois, A. and Gadde, L. (2002), "Systematic combining: an abductive approach to case research", Journal of Business Research, Vol. 55 No. 7, pp. 553-560.

Ely, R., Insead, H. and Kolb, D. (2011), "Taking gender into account: theory and design for women's leadership development programs", Academy of Management Learning \& Education, Vol. 10 No. 3, pp. 474-493.

Gallant, A. (2014), "Symbolic interactions and the development of women leaders in higher education", Gender, Work \& Organization, Vol. 21 No. 3, pp. 203-216. 
Gladwell, M. (2002), “The talent myth”, The New Yorker, 22 July, pp. 28-33.

Harding, S.G. (1986), The Science Question in Feminism, Cornell University Press, Ithaca.

Hirdman, Y. (2003), Genus: Om Det Stabilas Föränderliga Former, 2nd revised ed., Liber, Malmö.

Holgersson, C. (2013), "Recruiting managing directors: doing homosociality", Gender, Work and Organization, Vol. 20 No. 4.

Holgersson, C., Wahl, A., Linghag, S. and Regnö, K. (2014), "Ökad medvetenhet men långsam förändring: om kvinnor och män på ledande positioner i svenskt näringsliv", in Wittbom, E. (Eds), Att Spränga Normer: Om Målstyrningsprocesser för Jämställdhetsintegrering, Företagsekonomiska institutionen, Stockholms Universitet, Stockholm.

Hoobler, J.M., Lemmon, G. and Wayne, S.J. (2014), “Women's managerial aspirations an organizational development perspective", Journal of Management, Vol. 40 No. 3, pp. 703-730.

Jönsson, S., Muhonen, T., Scholten, C. and Wigerfelt, A. (2014), "Illusive inclusion-construction of leaders and employees based on nationality", Cross Cultural Management: An International Journal, Vol. 21 No. 2, pp. 245-260.

Joshi, A., Neely, B., Emrich, C., Griffiths, D. and George, G. (2015), "Gender research in AMJ: an overview of five decades of empirical research and calls to action thematic issue on gender in management research", Academy of Management Journal, Vol. 58 No. 5, pp. 1459-1475.

Kiaye, R.E. and Singh, M.A. (2013), "The glass ceiling: a perspective of women working in Durban", Gender in Management: An International Journal, Vol. 28 No. 1, pp. 28-42.

King, E.B., Botsford, W., Hebl, M.R., Kazama, S., Dawson, J.F. and Perkins, A. (2012), "Benevolent sexism at work gender differences in the distribution of challenging developmental experiences", Journal of Management, Vol. 38 No. 6, pp. 1835-1866.

Kunze, A. and Thorburn, K.S. (Ed.) (2014), Yrke, Karriär Och Lön: Kvinnors Och Mäns Olika Villkor På Den Svenska Arbetsmarknaden, SOU 2014:81, Forskningsrapport till Delegationen för jämställdhet i arbetslivet, Fritz, Stockholm, pp. 165-187.

Kvale, S. (2007), Doing Interviews, Sage Publications, Thousand Oaks, CA.

Ledarna (2014), "Livsmedels - Branschen ur ett Chefsperspektive en Branschrapport från the ledarna [The food industry - from the bosses perspective an Industry report from the leaders]", available at: www.ledarna.se/globalassets/foreningar/branschbevakning/rapport_livsmedelsbranschen_ ur_ett_chefsperspektiv-2.pdf (accessed February 2015).

Leidner, R. (1991), "Serving hamburgers and selling insurance: gender, work, and identity in interactive service jobs", Gender and Society, Vol. 5 No. 2, pp. 154-177.

Linghag, S. (2009), "Från medarbetare till chef: kön och makt i chefsförsörjning och karriär", Doctoral dissertation, Kungilga Tekniska högskolan, Stockholm.

Lipman-Blumen, J. (1976), "Toward a homosocial theory of sex roles: an explanation of the sex segregation of social institutions", Signs, Vol. 1 No. 3, pp. 15-31.

Liu, H., Cutcher, L. and Grant, D. (2015), "Doing authenticity: the gendered construction of authentic leadership", Gender, Work \& Organization, Vol. 22 No. 3, pp. 237-255.

Lombardo, E., Meier, P. and Verloo, M. (2009), The Discursive Politics of Gender Equality: Stretching, Bending and Policymaking, Routledg, New York, NY.

Mäkelä, K., Björkman, I. and Ehrnrooth, M. (2010), "How do MNCs establish their talent pools? Influences on individuals' likelihood of being labeled as talent", Journal of World Business, Vol. 5 No. 2, pp. 134-142.

Mark, E. (2007), Jämställdhetsarbetets Teori och Praktik, Studentlitteratur, Lund.

Muhonen, T., Liljeroth, C. and Scholten, C. (2012), Vad innebär Jämn Könsfördelning På Mellanchefsnivå för Den Kvalitativa Jämställdheten $i$ Organisationen?, Slutrapport, Malmö högskola, Malmö. 
GM

32,1

64

Oakley,J.G. (2000), "Gender-based barriers to senior management positions: understanding the scarcity of female CEOs", Journal of Business Ethics, Vol. 27 No. 4, pp. 321-334.

Ohlott, P.J., Ruderman, M.N. and McCauley, C.D. (1994), "Gender differences in managers' developmental job experiences”, Academy of Management Journal, Vol. 37 No. 1, pp. 46-67.

Pini, B. (2005), "The third sex: women leaders in Australian agriculture", Gender, Work \& Organization, Vol. 12 No. 1, pp. 73-88.

Powell, A., Bagilhole, B. and Dainty, A. (2009), "How women engineers do and undo gender: consequences for gender equality”, Gender, Work \& Organization, Vol. 16 No. 4, pp. 411-428.

Rees, B. and Garnsey, E. (2003), "Analysing competence: gender and identity at work”, Gender, Work \& Organization, Vol. 10 No. 5, pp. 551-578.

Rönnblom, M. (2011), "Vad är problemet?: konstruktioner av jämställdhet i svensk politik”, Tidskrift för genusvetenskap, 2 March, pp. 33-55.

Scholten, C. (2012), Makten Över Maten, En Fråga om Perspektiv, Malmö University, Malmö.

Schuler, R.S., Jackson, S.E. and Tarique, I. (2011), "Global talent management and global talent challenges: strategic opportunities for IHRM", Journal of World Business, Vol. 46 No. 4, pp. 506-516.

Scullion, H. and Collings, D. (2011), Global Talent Management, Routledge, New York, NY.

SFS, The Swedish Code of Statutes (1991), Act on Equality between Women and Men, SFS 1991: 433, Swedish Ministry of Integration and Gender Equality, Ministry of Culture, Stockholm.

SOU (1990), 44 Demokrati och makt i Sverige [Democracy and Power in Sweden], Maktutredningens huvudrapport, Statens offentliga utredningar, Allmänna förlaget, Stockholm.

Squires, J. (2007), The New Politics of Gender Equality, Palgrave Macmillan, Basingstoke.

Strauss, A. and Corbin, J. (1998), Basics of Qualitative Research: Techniques and Procedures for Developing Grounded Theory, 2nd ed., Sage Publications, Thousand Oaks, CA.

Svenska Kommunförbundet (2002), "Aktivit jämställdhetsarbete Jämtegrering och 3R-metoden i kommunala verksamheter", available at: www.jamstall.nu/wp-content/uploads/2014/02/AktivtJämställdhetsarbete--Jämtegrering-och-3R-metoden-i-kommunala-verksamheter-SvenskaKommunförbundet1.pdf (accessed February 2014).

Tienari, J., Meriläinen, S., Holgersson, C. and Bendl, R. (2013), "And then there are none: on the exclusion of women in processes of executive search", Gender in Management: An International Journal, Vol. 28 No. 1, pp. 43-62.

Verloo, M. (2001), "Another velvet revolution? Gender mainstreaming and the politics of implementation”, Working Paper No. 5, IWM, Vienna.

Verloo, M. (ed.) (2007), Multiple Meanings of Gender Equality: A Critical Frame Analysis of Gender Policies in Europe, CEU Press, New York, NY.

Walby, S. (2005), "Gender mainstreaming: productive tension in theory and practice", Social Politics, Vol. 12 No. 3, pp. 321-343.

Wittbom, E. (2009), Att Spränga Normer: Om Målstyrningsprocesser för Jämställdhetsintegrering, Företagsekonomiska institutionen, Stockholms Universitet, Stockholm.

Yin, R.K. (1994), Case Study Research: Design and Methods, 2nd ed., Sage Publications, Thousand Oaks, CA.

\section{Further reading}

SCB (2012), Kvinnor Och Män i Näringslivet 2012, Statiska Centralbyran, Örebro.

SCB (2014), Kvinnor Och Män i Näringslivet 2014, Statiska Centralbyran, Örebro.

Wahl, A. (1992), "Könsstrukturer i Organisationer. Kvinnliga civilekonomers och civilingenjörers karriärutveckling”, Doctoral dissertation, Handelshögskolan, Stockholm. 


\begin{abstract}
About the authors
Christina Scholten holds a PhD in Social and Economic Geography with a focus on regional development policy, work-life and gender. She has been doing research on gender mainstreaming in innovation development organizations and gender in management training. Current research projects include gender perspective on regional transport planning and sustainable collaborative methods for sustainable public transport. She is employed as an Assistant Professor in the Urban Studies department at Malmö University. Since 2010, she has been involved in successfully building the Swedish National Public Transport Research Centre and held the position of Acting Director during 2014.

Hope Witmer holds a PhD in Applied Management and Decision Sciences with a focus on leadership and organizational change. Her research areas include leadership and organization from a resilience, sustainability and gender perspective. She is employed as an Assistant Professor in the Urban Studies department at Malmö University and a researcher for the Center for Worklife and Evaluation Studies (CTA) at Malmö University. Her previous experience includes Assistant Dean of graduate programs at Lebanon Valley College, Pennsylvania, USA, and she has worked as a healthcare management and organizational consultant. Hope Witmer is the corresponding author and can be contacted at: hope.witmer@mah.se
\end{abstract}

For instructions on how to order reprints of this article, please visit our website: www.emeraldgrouppublishing.com/licensing/reprints.htm Or contact us for further details: permissions@emeraldinsight.com 